\title{
CORRIGENDUM
}

\section{Divergent functional isoforms drive niche specialisation for nutrient acquisition and use in rumen microbiome}

Francesco Rubino, Ciara Carberry, Sinéad M Waters, David Kenny, Matthew S McCabe and Christopher J Creevey

The ISME Journal (2017) 11, 1510; doi:10.1038/ismej.2017.34

Correction to: The ISME Journal (2017) 11, 932-944; doi:10.1038/ismej.2016.172

Updated online 28 February 2017: This article was originally published under a CC BY-NC-SA 4.0 license, but has now been made available under a CC-BY 4.0 license. The PDF and HTML versions of the paper have been modified accordingly. (c) (1) This work is licensed under a Creative Commons Attribution 4.0 International License. The images or other third party material in this article are included in the article's Creative Commons license, unless indicated otherwise in the credit line; if the material is not included under the Creative Commons license, users will need to obtain permission from the license holder to reproduce the material. To view a copy of this license, visit http://creativecommons.org/ licenses/by/4.0/

(c) The Author(s) 2017 